\title{
Shrimp/prawn farming status in south-west region of Bangladesh in context of quality control and food safety issues
}

\author{
M.S. KHATUN*, M. ARIFUL ISLAM AND K.K.U. AHMED \\ Bangladesh Fisheries Research Institute \\ Shrimp Research Station, Bagerhat 9300, Bangladesh \\ *Email: subrinakhatun@gmail.com
}

\begin{abstract}
To determine hazardous antibiotics/chemicals and pesticides residues in Good Aquaculture Practice (GAP) and non-GAP farms and exploring the post-harvest management techniques of shrimp/ prawn for ensuring its food safety issues, a study was conducted from July 2016 to June 2019 in three upazilas viz. Bagerhat Sadar, Rampal and Kachua of Bagerhat district. A total of 550 shrimp/prawn farms were randomly surveyed considering GAP criteria. The farms were categorized as Category A- the farms which comply 90$100 \%$ GAP criteria; Category B- farms which comply $70-<90 \%$ GAP criteria and Category C- farms which comply $50-<70 \%$ GAP criteria. From the study it was found that only $1.67 \pm 0.58 \%$ farms were under Category-A, $37.67 \pm 6.81 \%$ farms were under Category-B and $53 \pm 6.08 \%$ farms were under Category-C. A total of 108 shrimp/prawn samples were collected in which $30 \%$ samples were from GAP farms and $70 \%$ samples were from non-GAP farms. Collected samples were analyzed for hazardous antibiotics/chemicals and pesticides residues (Heptachlor, Endrin, Dieldrin and DDT) using LC-MS and GC-MS machine. No hazardous Nitrofuran and Chloramphenicol metabolites were found from the collected samples and no residual concentrations of Heptachlor, Endrin, Dieldrin and DDT were found from GAP samples. In nonGAP samples, $14.8 \%$ samples contained some residues of Heptachlor, Endrin and Dieldrin in which $10.2 \%$ samples residues were lower than the Maximum Residual Limit (MRL) which is not harmful for human health. Only $4.6 \%$ samples had residues which were slightly higher than the MRL. Exploration of postharvest management techniques of shrimp and prawn were done by observing the icing system quality and transportation system from farms to market/depot. It was found that $5.67 \pm 2.08 \%$ farmer used proper icing and transportation system as well, $16.33 \pm 3.21 \%$ farmers used moderate icing and transportation system and $78 \pm 2 \%$ farmers used poor icing and transportation system. It was also observed that pathogenic bacterial load was higher in poor icing and transportation system as well than the proper icing and transportation system. From the study it can be concluded that, if farmers follow at least $50 \%$ of the GAP criteria then the foods (shrimp/prawn) will be safer for human consumption.
\end{abstract}

Keywords: Good Aquaculture Practice, Antibiotics, Pesticides, Food safety issues

\section{Introduction}

Bangladesh is one of the pioneers of frozen sea food exporters' country and ship mainly frozen shrimps to mainstream market in the USA, EU, Japan, Saudi Arabia, the UAE and Gulf States (Ali et al. 2012, Khan et al. 2012). However, the exported shrimp is rejected many times by the importing countries because of high bacterial load, decomposition and due to the presence of filth, unexpected foreign materials as well as pathogenic microbes (Escheritia coli, Salmonella, Vibrio cholerae etc.). After 17 December, 1997 it was mandatory to prepare all the seafood products under the HACCP regulations (USFDA 1997). Good Manufacturing Practices (GMP) as well as Good Aquaculture Practices (GAP) and sanitation are the perquisite for the implementation of HACCP system. Now-a-days, imported countries have developed standard criteria and a full certification system for the shrimp production line from farm to table. In recent times, the GMP and sanitation procedures of many fish processing plants are excellent, hence their product performance (quality) earn a better place in the foreign markets. However, 
sometimes remarkable contamination in shrimp is found due to improper management in culture stage. That's why GAP has become a mandatory task for implementation of HACCP system in a better way. GAP are a series of considerations, procedures and protocols designed to foster efficient and responsible aquaculture production and expansion and to help in ensuring the final product quality, safety and environmental sustainability (Schwarz et al. 2010).

In south-west region of Bangladesh, shrimp/prawn is cultured mostly with rice and farmers use indiscriminately different groups of pesticides to control pest in rice. Some of these pesticides residues are gradually accumulating in shrimp/prawn body. In Bangladesh, import and production of all types of Persistent Organic Pollutants (POPs) like DDT and heptachlor is banned but at least five POPs pesticides including DDT are still in use under different name or label. Besides, some banned antibiotics such as Nitrofurans, Chloramphenicol, Malachite green, Leuco Malachite green etc. also accumulating in shrimp/prawn which are mostly approved for veterinary products and used in farms for disease control and shrimp/prawn health management. All of these products are highly carcinogenic and threatening for food safety. According to WHO estimation, 1.8 million deaths related to contaminated food or water occurs every year. According to EU regulation for shrimp/prawn as well as other frozen food exportation, appearance of any type of pesticides and chemical residues is fully prohibited. In this context, consciousness of our farmers is inadequate. So, it is very much essential to identify and quantify of these pesticides and antibiotics residues for assessment of risk on human health.

\section{Materials and Methods}

\section{Expt. I: Survey the existing shrimp farms for exploration of its present farming status based on GAP (Good Aquaculture Practice)}

This survey were conducted in the shrimp farming areas for 3-4 months and data were collected from 550 randomly selected shrimp farms considering the following GAP Criteria : (i) Good Practice Status in Site Selection for Shrimp, (ii) Good Practice Status in Farming, (iii) Good Practice Status in Water Use, (iv) Good Practice Status in Surrounding Environment and Pest Control of the Farm, (v) Good Practice Status in Feed Management, (vi) Good Practice Status in Disease Management, and (vii) Good Practice Status in Harvesting and Post Harvesting Management. The experimental design is shown in Table I.

Table I. Experimental design

\begin{tabular}{|l|l|l|l|l|}
\hline Sampling Site & Survey type & Survey method & $\begin{array}{l}\text { Surveyed } \\
\text { farms }\end{array}$ & Target aspects \\
\hline $\begin{array}{l}\text { Bagerhat Sadar, } \\
\text { Rampal, Kochua } \\
\begin{array}{l}\text { Upazila of } \\
\text { Bagerhat district }\end{array}\end{array}$ & $\begin{array}{l}\text { Questionnaire } \\
\text { Survey }\end{array}$ & $\begin{array}{l}\text { Random Survey from } \\
\text { shrimp/praw farms } \\
\text { and in few cases from } \\
\text { market with PRA } \\
\text { method }\end{array}$ & $\begin{array}{l}20 \text { nos. } \\
\text { /Union }\end{array}$ & $\begin{array}{l}\text { Site Selection, Farming } \\
\text { management, Water Use, } \\
\text { Surrounding Environment } \\
\text { and Pest Control of the }\end{array}$ \\
& & $\begin{array}{l}\text { Farm, Feed Management, } \\
\text { Disease Management as } \\
\text { well as Harvesting and Post } \\
\text { Harvesting Management }\end{array}$ \\
\hline
\end{tabular}


Expt. II: Assessment of the hazardous antibiotics/chemicals and pesticides residues to determine shrimp/prawn quality

Table II. Experimental design

\begin{tabular}{|c|c|c|c|c|c|}
\hline $\begin{array}{l}\text { Sampling } \\
\text { sites }\end{array}$ & $\begin{array}{l}\text { Sampling } \\
\text { farms }\end{array}$ & $\begin{array}{l}\text { No. of sampling } \\
\text { (monthly) }\end{array}$ & Sample species & $\begin{array}{l}\text { Sample } \\
\text { weight }\end{array}$ & Target analyses \\
\hline \multirow{2}{*}{$\begin{array}{l}\text { Bagerhat } \\
\text { Sadar, } \\
\text { Rampal, } \\
\text { Kochua } \\
\text { Upazila of } \\
\text { Bagerhat } \\
\text { district }\end{array}$} & $\begin{array}{l}\text { GAP } \\
\text { farm }\end{array}$ & $\begin{array}{l}05 \text { (Approx.) } \\
\text { based on survey } \\
\text { result }\end{array}$ & \multirow[t]{2}{*}{$\begin{array}{l}\text { M. rosenbergii / } \\
P . \text { monodon }\end{array}$} & \multirow[t]{2}{*}{$500 \mathrm{~g}$} & \multirow{2}{*}{$\begin{array}{l}\text { Antibiotics: Nitrofuran } \\
\text { Metabolites, } \\
\text { Chloramphenical) } \\
\text { Pesticides: Organochlorine } \\
\text { pesticides such as DDT, } \\
\text { Dieldrin, Heptachlor, } \\
\text { Endrin }\end{array}$} \\
\hline & $\begin{array}{l}\text { non-GAP } \\
\text { farm }\end{array}$ & $\begin{array}{l}05 \text { (Approx.) } \\
\text { based on survey } \\
\text { result }\end{array}$ & & & \\
\hline
\end{tabular}

Sampling procedure: From the surveyed farms, $10 \%$ farms were selected as sampling sites. Multisampling was done whenever necessary. Shrimp and prawn samples were collected randomly from the farms when those attained $3+$ months age. Then those were brought into Quality Control lab. of Shrimp Research Station (SRS) and preserved in refrigerator for further analysis.

Extraction, derivatization and clean-up procedures for antibiotic test using LC-MS/MS: Frozen whole shrimp and prawn were thawed, rinsed under running water, and the shell and head were removed. Muscle was chopped with knife on a clean board and collected in a beaker and kept in the fridge until analysis. About $2.0 \mathrm{~g}$ of chopped sample was taken into $50 \mathrm{ml}$ PEcentrifugation tube. Then $4 \mathrm{ml}$ HPLC-Water and $3 \mathrm{~mL} 1 \mathrm{M}$ HCL was added. The mixture was homogenized using Ultra Terex for 2 minutes. Washing the rotor with HPLC water was done in order to make sure that the total volume do not to exceed $17 \mathrm{ml}$. Adding of $400 \mu \mathrm{l}$ of 2nitrobenxaldehyde solution and $500 \mu l$ internal standards were insured. The PE-centrifugation tubes with the dedicated cap was kept in the dark at room temperature in the water bath keeping at constant $37^{\circ} \mathrm{C}$ for 16 hours for derivatization. In order to adjust the $\mathrm{pH}$ adding of $2 \mathrm{ml}$ dipotassium hydrogen phosphate solution and $2.5 \mathrm{~mL} 0.8 \mathrm{~mol} / \mathrm{L} \mathrm{NaOH}$ (aq.) was done. When necessary $0.125 \mathrm{~mol} / \mathrm{L}$ hydrochloric acid or the $0.125 \mathrm{~mol} / \mathrm{L}$. $\mathrm{NaOH}$ (aq.) were used to adjust the $\mathrm{pH}$ 7. After that $8 \mathrm{ml}$ ethyl acetate was added and shaked for $5 \mathrm{~min}$ and centrifuged for 5 $\min$ at $4000 \mathrm{rpm}$ and the ethyl acetate phase (upper phase) was transferred to a $15 \mathrm{ml}$ centrifugation tube. The sample was extracted again with $4 \mathrm{ml}$ ethyl acetate, centrifuged and combined the ethyl acetate phases in the $15 \mathrm{ml}$ PE-centrifugation tube. Concentration of the extract was done at $45^{\circ} \mathrm{C}$ under the stream of dry nitrogen. Then the residue was mixed with 1.0 $\mathrm{ml}$ methanol: water $(50 \% / 50 \%)$ and $1.0 \mathrm{ml}$-hexane in $15 \mathrm{ml} \mathrm{PE}$ centrifugation tube, for centrifugation at $4000 \mathrm{rpm}$ at $5 \mathrm{~min}$ at $4^{\circ} \mathrm{C}$. The upper hexane phase was discarded by using disposable syringe and long needle syringe was used to draw the bottom (clear) part into the syringe. Then it was filtered by $0.25 \mu \mathrm{m}$ syringe filter to the vial. At last, the vial with sample was taken for injection by LCMS/MS API 3200.

Extraction and clean-up procedure for pesticides residue analysis using GC-MS/MS: The extraction was carried out according to the procedure described by QuEschERS Method and 
necessary modification was also adopted for extraction, separation and clean-up sample. $10 \mathrm{~g}$ of shrimp and prawn sample was taken in a Teflon tube. $20 \mathrm{ml}$ ethyl-acetate/aceto-nitrile was added to it and hand shaken for $1 \mathrm{~min}$. Then it had to shake with vortex mixture for $2 \mathrm{~min}$ and $1.5 \mathrm{~g} \mathrm{NaCl}$ and $6 \mathrm{~g}$ anhydrous $\mathrm{MgSO}_{4}$ was added to it and then hand shaken for $1 \mathrm{~min}$. Again it had to shake with vortex mixture for $1 / 2 \mathrm{~min}$. Then it was filtered with $20 \mathrm{~g} \mathrm{NaSO} 4$ and $10 \mathrm{~mL}$ anhydrous ethyl-acetate. The mixture had to centrifuge at $5000 \mathrm{rpm}$ for 5 minutes. Then $10 \mathrm{ml}$ supernatant was taken in a round bottom flask. The supernatant was evaporated with rotary evaporator keeping temperature not more than $40^{\circ} \mathrm{C} .5 \mathrm{ml}$-hexane was added in a round bottom flask. Then $2 \mathrm{ml} \mathrm{n}$-hexane soln. was taken in a test tube.

For cleaning-up: $2 \mathrm{ml} \mathrm{H}_{2} \mathrm{SO}_{4}$ was added with that $2 \mathrm{ml} \mathrm{n}$-Hexane soln. Then it was vortex for 1 min. After vortex the mixture was centrifuged at $4000 \mathrm{rpm}$ for 3 minutes. After that the supernatant was taken in a tube and was filtered with $0.45 \mu \mathrm{g}$ syringe filter in a vial. Then finally $2 \mathrm{~mL}$ sample was taken in a vial for GC-ECD or GC-FID analysis.

Expt. III: Post-harvest management techniques of shrimp/prawn to ensure food safety issues

Table III: Experimental Design

\begin{tabular}{|c|c|c|c|c|c|c|}
\hline \multirow{2}{*}{$\begin{array}{l}\text { Sampling } \\
\text { Sites }\end{array}$} & \multirow{2}{*}{$\begin{array}{l}\text { Sampling } \\
\text { farms }\end{array}$} & \multicolumn{2}{|c|}{ No. of sampling (monthly) } & \multirow{2}{*}{$\begin{array}{l}\text { Sample } \\
\text { Species }\end{array}$} & \multirow{2}{*}{$\begin{array}{c}\text { Sample } \\
\text { weight }\end{array}$} & \multirow[t]{2}{*}{ Analysis aspects } \\
\hline & & $\begin{array}{l}\text { Sampling } \\
\text { from farms }\end{array}$ & $\begin{array}{c}\text { Sampling } \\
\text { from local } \\
\text { market/ depot }\end{array}$ & & & \\
\hline \multirow{2}{*}{$\begin{array}{l}\text { Bagerhat } \\
\text { Sadar, } \\
\text { Rampal, } \\
\text { Kochua } \\
\text { Upazila of } \\
\text { Bagerhat } \\
\text { district }\end{array}$} & $\begin{array}{l}\text { GAP } \\
\text { following } \\
\text { farm }\end{array}$ & $\begin{array}{l}05 \text { (Approx.) } \\
\text { based on } \\
\text { survey result }\end{array}$ & 05 & \multirow{2}{*}{$\begin{array}{l}M . \\
\text { rosenbergii } \\
/ P . \\
\text { monodon }\end{array}$} & \multirow[t]{2}{*}{$500 \mathrm{~g}$} & \multirow{2}{*}{$\begin{array}{l}\text { Risk analysis through } \\
\text { risk assessment, Risk } \\
\text { management, Risk } \\
\text { communication, } \\
\text { Hazard identification, } \\
\text { Hazard } \\
\text { characterization, } \\
\text { Exposure assessment, } \\
\text { Risk characterization }\end{array}$} \\
\hline & $\begin{array}{l}\text { non-GAP } \\
\text { farm }\end{array}$ & $\begin{array}{l}05 \text { (Approx.) } \\
\text { based on } \\
\text { survey result }\end{array}$ & 05 & & & \\
\hline
\end{tabular}

Sampling and analysis procedure: Samples were collected randomly from the farms when those became attain $3+$ months age. Same samples of pre-selected farms were collected from the market/depot after their transportation from farm to market. Then their icing quality as well as transportation quality was observed to ensure food safety. Food safety issues were ensured after risk analysis through risk assessment, risk management, risk communication, hazard identification, hazard characterization, exposure assessment, risk characterization process.

Issues concerning risk analysis: (i) Icing system has been observed from farm to depot/market, (ii) Marketing chain/channel observation, (iii) Transportation techniques was observed from farm to depot/market.

Statistical analysis: Statistical analysis was done using MS-EXCELL as well as SPSS software for the meaningful interpretation of the research outputs. 


\section{Results and Discussion}

Expt. I: Survey of shrimp farms for exploration of its present farming status based on GAP

A comprehensive survey was conducted randomly among 550 farms of Bagerhat Sadar, Rampal, and Kochua Upazila of Bagerhat district covering 27 Unions. On the basis of surveyed data, the surveyed farms were categorized into 03 categories viz. Category-A, Category-B and Category$\mathrm{C}$ where Category-A indicates the farms which comply 90-100\% GAP criteria; Category-B indicates the farms which comply $70-<90 \%$ GAP criteria and Category-C indicates the farms which comply $50-<70 \%$ GAP criteria. Then from the surveyed data, it was found that $1.67 \pm 0.58$ percent farms were under Category-A, $37.67 \pm 6.81$ percent farms were under Category-B and $53 \pm 6.08$ percent farms were under Category-C. Rest of the farms $(7.67 \pm 1.53$ percent) did not follow the criteria of GAP (Table IV).

Table IV. Present status of shrimp farms at Bagerhat Sadar, Rampal, Kochua Upazila, Bagerhat

\begin{tabular}{l|c}
\hline Category of Farms & Percentage of Farms (\%) (Mean \pm SD) \\
\hline Category-A & $1.67 \pm 0.58$ \\
\hline Category-B & $37.67 \pm 6.81$ \\
\hline Category-C & $53 \pm 6.08$ \\
\hline Out of GAP Category & $7.67 \pm 1.53$ \\
\hline
\end{tabular}

Expt. II: Assessment of the hazardous antibiotics/chemicals and pesticides residues for determination of shrimp/prawn quality of GAP and non -GAP farms

Assessment of antibiotic residues in shrimp/prawn farms: For analysis of banned antibiotic Nitrofuran and Chloramphenicol, the shrimp and prawn samples were analyzed by LC-MS following standard analysis protocol. No hazardous Nitrofuran and Chloramphenicol metabolites were found from shrimp and prawn samples collected from sampling farms (Table V).

Table V. Tested parameters of hazardous antibiotic residue in collected samples

\begin{tabular}{|c|c|c|c|c|c|}
\hline Test Parameter & $\begin{array}{l}\text { MRPL/RPA } \\
\text { (ppb) }\end{array}$ & $\begin{array}{l}\text { Reporting } \\
\text { limit (ppb) }\end{array}$ & Result (ppb) & Method of test & $\begin{array}{c}\text { Analytical } \\
\text { tools }\end{array}$ \\
\hline \multicolumn{6}{|c|}{ Nitrofuran Metabolites } \\
\hline AMOZ & 1.0 & 0.32 & Not Detected & \multirow{4}{*}{$\begin{array}{c}\text { FLD CD TMSOP- } \\
03 \text { V.4 }\end{array}$} & \multirow{5}{*}{$\begin{array}{c}\text { Analysis } \\
\text { was carried } \\
\text { out by LC } \\
\text { MS/MS }\end{array}$} \\
\hline $\mathrm{AOZ}$ & 1.0 & 0.26 & Not Detected & & \\
\hline AHD & 1.0 & 0.19 & Not Detected & & \\
\hline SEM & 1.0 & 0.34 & Not Detected & & \\
\hline Chloramphenicol & 0.3 & 0.08 & Not Detected & $\begin{array}{c}\text { FLD CD TMSOP- } \\
01 \mathrm{~V} .2\end{array}$ & \\
\hline
\end{tabular}


Nitrofurans, particularly Furazolidone (FZD), Furaltadone (FTD), Nitrofurantoin (NFT) and Nitrofurazone (NFZ), belong to a class of synthetic broad spectrum antibiotics which contain a characteristic 5-nitrofuran ring. Nitrofaurans were commonly used in aquaculture as feed additive (Draisci et al. 1997). In 1995, EU banned the use of antibiotic due to concerns about the carcinogenicity of the drug residues and their potential harmful effects on human health (Van Koten-Vermeulen 1993). Since 1993, the use of nitrofurans in agriculture, livestock and aquaculture has also been prohibited in many countries like Australia, USA, Philippines, Thailand and Brazil because of a possible increased cancer-risk through long-term consumption (Khong et al. 2004). Like Nitrofaurans, Oxytetracycline is generally considered a very stable substance in the environment, with half-life of 101 to 364 days (Rahman 2013).

Assessment of pesticide residues in shrimp and prawn farms: Shrimp and prawn samples were collected from sampling sites for pesticidal residue analysis. A total of $108 \mathrm{shrimp} / \mathrm{prawn}$ samples were collected from the sampling site in which $30 \%$ samples were from the GAP farms and $70 \%$ samples were from the non-GAP farms. The samples were analyzed for DDT, Dieldrin, Endrin and Heptachlore using GC-MS Machine following standard analysis protocol. Analyzed report from ECD detector of Gas Chromatography shows that no residual concentrations of Heptachlor, Endrin, Dieldrin and DDT were found from the GAP samples. In the non-GAP samples, $14.8 \%$ contained some residues of Heptachlor, Endrin, Dieldrin and DDT in which $10.2 \%$ samples residues were lower than the Maximum Residual Limit (MRL) which is not harmful for human health. Only $4.6 \%$ samples had residues which were slightly higher than the MRL (Table VI).

Table VI. Residual concentration of hazardous pesticides in collected sample

\begin{tabular}{|c|c|c|c|c|c|}
\hline Sampling sites & Upazila & $\begin{array}{l}\text { Heptachlor } \\
\text { (ppm) }\end{array}$ & $\begin{array}{c}\text { Dieldrin } \\
(\mathrm{ppm})\end{array}$ & $\begin{array}{c}\text { Endrin } \\
(\mathrm{ppm})\end{array}$ & $\begin{array}{l}\text { DDT } \\
\text { (ppm) }\end{array}$ \\
\hline Badhal & \multirow[t]{7}{*}{ Kochua } & 00 & 0.022 & 00 & 00 \\
\hline Dhopakhali & & 00 & 00 & 00 & 00 \\
\hline Gopalpur & & 00 & 0.018 & 00 & 00 \\
\hline Moghia & & 00 & 0.012 & 00 & 00 \\
\hline Raripara & & 00 & 0.012 & 00 & 00 \\
\hline Gozalia & & 00 & 0.010 & 00 & 00 \\
\hline Kochua Sadar & & 00 & 0.025 & 00 & 00 \\
\hline Bagerhat Sadar & \multirow{3}{*}{$\begin{array}{l}\text { Bagerhat } \\
\text { sadar }\end{array}$} & 0.042 & 0.086 & 0.391 & 00 \\
\hline Karapara & & 00 & 0.00023 & 00 & 00 \\
\hline Jatrapur & & 0.00019 & 00 & 00 & 00 \\
\hline Gurumba & \multirow[t]{3}{*}{ Rampal } & 0.00031 & 00 & 00 & 00 \\
\hline Rajanagar & & 0.00014 & 00 & 00 & 00 \\
\hline Rampal Sadar & & 0.00012 & 00 & 00 & 0.00022 \\
\hline Acceptable limit & & 0.01 & 0.02 & 0.01 & 0.05 \\
\hline
\end{tabular}

Zaman et al. (2012) studied the level of organochlorine pesticide residues (OCPs), viz. $\alpha-$, $\beta-, \gamma$-BHC, heptachlor, aldrin, heptachlor epoxide isomer B, dieldrin, 4,4'-DDE, endrin, 2,4DDD, 4,4'-DDT, 4,4'-DDD, 2,4'-DDT in fish samples from Matlab floodplain areas. The result showed that none of the studied fishes contained organochlorine pesticide residues but 
consist some other harmful organic contaminants in tissues. Rahman (2013) studied on organochlorine pesticides in marine sediments along the coast of Alicante, Spain. The levels of organochlorines in sediments were low.

\section{Expt. III: Post-harvest management of shrimp/prawn to ensure food safety issues}

The experiment about the exploration of post-harvest management techniques of shrimp/prawn for ensuring its food safety issues was done by observing the icing system quality and transportation system quality from farms to market/depot. It was found that $(5.67 \pm 2.08) \%$ farmers used proper icing and transportation system, $(16.33 \pm 3.21) \%$ farmers used moderate icing and transportation system, and $(78 \pm 2) \%$ farmers used poor icing and transportation system (Table VII). It was also observed that pathogenic bacterial load was higher in poor icing and transportation system as well than the proper icing and transportation system.

Table VII. Observation of icing and transportation system quality from farms to market /depot

\begin{tabular}{l|c|c|c}
\hline Icing System Quality & $\%$ of Farms & $\begin{array}{c}\text { Duration } \\
\text { (from farm to depot / market) }\end{array}$ & Risk category \\
\hline $\begin{array}{l}\text { Good } \\
\text { (Maintaining proper ice ratio) }\end{array}$ & $5.67 \pm 2.08$ & & Low \\
\hline $\begin{array}{l}\text { Moderate } \\
\text { (Not maintaining proper ice ratio) }\end{array}$ & $16.33 \pm 3.21$ & \multirow{2}{*}{0.5 to $2 \mathrm{hrs.}$} & Medium \\
\hline Poor (No icing) & $78 \pm 2$ & & High \\
\hline
\end{tabular}

\section{Conclusions}

In the present study, no residual concentrations of Heptachlor, Endrin, Dieldrin and DDT were found from GAP samples. In non-GAP samples, $14.8 \%$ samples comprising some residues of Heptachlor, Endrin, Dieldrin and DDT in which $10.2 \%$ samples residues were lower than the Maximum Residual Limit (MRL) which is not harmful for human health. Only $4.6 \%$ samples had residues which were slightly higher than the MRL. Though the presence of residues was found much lower than the acceptable limit but everyone should be aware about the indiscriminate use of pesticides, chemicals and aqua drugs because it may be harmful for the safe food production in the near future and more study is needed for the quantification of residues in shrimp/prawn in both captured and cultured fishery. It can be concluded from the study that, if farmers follow at least $50 \%$ of the GAP criteria then the foods (shrimp/prawn) will be safer for human consumption.

\section{Literature Cited}

Ali, M.Y., M.B. Hossain and M. Shamsuddin, 2012. Microbiological status in a fully exportoriented shrimp processing plant. World Appl. Sci. J., 16(7): 903-906.

Draisci, R., L. Giannetti, L. Lucentini, L. Palleschi, G. Brambilla, L. Serpe and P. Gallo, 1997. Determination of nitrofuran residues in avian eggs by liquid chromatography UV photodiode array detection and confirmation by liquid chromatography ion spray mass spectrometry. J. Chromat., A, 777: 201-211. 
Khan, N.S., M.R. Islam, M.B. Hossain, M.A. Quaiyum, M. Shamsuddin and J.K. Karmaker, 2012. Comparative analysis of microbial status of raw and frozen freshwater prawn (Macrobrachium rosenbergii). Middle-East J. Sci. Res., 12(7): 1026-1030.

Khong, S.P., E. Gremaud, J. Richoz, T. Delatour, P.A. Guy, R.H. Stadler and P. Mottier, 2004. Analysis of matrix-bound nitrofuran residues in worldwide-originated honeys by isotope dilution high-performance liquid chromatography-tandem mass spectrometry. $J$. Agric. Food Chem., 52 5309-5315.

Rahman M.K., 2013. Impact of aquaculture drugs and chemicals on aquatic ecology and productivity. Bangladesh Fisheries Research Institute, Bangladesh, 222 p.

Schwarz, M.H., M.L. Jahncke and A.M. Lazur, 2010. Overview of Good Aquaculture Practices. Virginia Cooperative Extension. Sea Grant Pub., VSG-09-07.

USFDA (United States Food and Drug Administration), 1997. Fish and Fisheries products hazards and controls guidance. 3 Ed. US Food and Drug Administration, Center for Food Safety and Applied Nutrition.

Van Koten-Vermeulen J.E.M., 1993. Report of the 40th Meeting of the Joint FAO/WHO Expert Committee On Food Additives (JECFA), World Health Organization, Geneva, 85 p.

Zaman, M., M.N. Naser, M. Hossain, M. Husain, A. Islam, K.A. Islam and N. Sultana, 2012. Pesticide residues and harmful organic pollutants in some freshwater fishes from Matlab floodplain area, Bangladesh, Bangladesh J. Zool., 40(1): 101-108. 